\title{
in vitro Antidiabetic, Antioxidant and Cytotoxic Activities of Syzygium cumini Fractions from Leaves Ethanol Extract
}

\author{
Nina Artanti ${ }^{1, *}$, Faiza Maryani ${ }^{1}$, Rizna Triana Dewi ${ }^{1}$, Sri Handayani ${ }^{2}$, \\ Indah Dwiatmi Dewijanti ${ }^{1}$, Lia Meilawati ${ }^{1}$, Euis Filaila ${ }^{1}$, Linar Zalinar Udin ${ }^{1}$ \\ ${ }^{1}$ Research Center for Chemistry, Indonesian Institute of Sciences, Banten, Indonesia \\ ${ }^{2}$ Research Unit for Natural Product Technology, Indonesian Institute of Sciences, Yogyakarta, Indonesia
}

\begin{abstract}
Ethanol extract of Syzygium cumini (jamblang) leaves reveal its significant a-glucosidase inhibitory activity which perform the potential activity of this plant extract as antidiabetic agent. However, other bioactivities of this plant extract have been reported. The aim of current study was to evaluate the comparison of in vitro antidiabetic, antioxidant and cytotoxic activity of S. cumini fractions. The S. cumini leaves ethanol extract was fractionated by using column chromatography with $\mathrm{n}$-hexane, ethyl acetate and methanol as eluents. Seven fractions were obtained from column chromatography (F1-7). The results showed that the best antidiabetic activity was found in F5 (93\% a-glucosidase inhibitory activity), the best antioxidant activity was found in F4 (83\% inhibition of DPPH free radical) and the best cytotoxic activity was found in F2 (69\% growth inhibition of T47D breast cancer cell line). Therefore besides in vitro antidiabetic activity, fractions of $S$. cumini leaves ethanol extract also showed antioxidant and cytotoxic activities. Since the results showed that the most active fractions for antidiabetic, antioxidant and cytotoxicity were differed, it could be possible to isolate the different potential active compounds for each activity.
\end{abstract}

Keywords : Syzygium cumini, a-glucosidase inhibitor, DPPH, cytotoxicity

\section{INTRODUCTION}

Syzygium cumini (L.) Skeels (Myrtaceae) is a traditional medicinal plant that has been used to treat a number of illnesses. This medicinal plant is native to the subtropical Himalayas, India, Sri Lanka, Malesia and Australia, where it is also widely cultivated. At present it is grown throughout the tropics and subtropics. This plant have synonyms as Eugenia jambolana Lam., Myrtus cumini Linn., Syzygium jambolana DC., Syzygium jambolanum (Lam.) DC., Eugenia djouant Perr., Calyptranthes jambolana Willd., Eugenia cumini (Linn.) Druce. and Eugenia caryophyllifolia Lam. Whereas the common names are jambolan, black plum, jamun, java plum, Indian blackberry, Portuguese plum, Malabar plum, purple plum, Jamaica and damson plum (Ayyanar and Subash-Babu, 2012).

S. cumini extracts prepared from its different parts, especially seed, and pulp-fruit has been

Submitted: November 8, 2018

Revised: December 17, 2018

Accepted: December 17, 2018

*Corresponding author: ninaartanti@gmail.com 
studied especially for antidiabetic and metabolicrelated activity. However, phytochemical profile and biological properties of its leaf is a lack of studies. Our previous studies on $70 \%$ ethanol extract of $S$. cumini leaves found significant in vitro ( $\alpha$-glucosidase inhibitory activity) and in vivo (animal model) antidiabetic activity which present the potential of this plant extract for diabetes treatment. Antioxidant activity of $S$. cumini is reported by Mohamed, et al., (2013) and Ruan, et al., (2008). Fruit extract of $S$. cumini shows cytotoxic activity on MCF-7 breast cancer cells (Tripathy and Pradhan, 2015). However, the comparison of antidiabetic, antioxidant and cytotoxic activity from $S$. cumini leaves fraction has never been reported yet. The aim of current study was to evaluate the comparison of in vitro antidiabetic, antioxidant and cytotoxic activity of $S$. cumini leaves fractions obtained from column chromatography of the leaves ethanol extract using n-hexane, ethyl acetate and methanol as eluents.

\section{MATERIALS AND METHODS}

\section{Material}

S. cumini leaves EtOH extract (6 gr) was fractionated in silica gel vacuum column chromatography using n-hexane, ethyl acetate and methanol as eluents (Hexane 100\%; Hexane: Ethyl Acetate 50\%; Ethyl Acetate 100\%; Ethyl Acetate: Methanol 25\%; Ethyl Acetate: Methanol 50\%; Ethyl Acetate: Methanol 75\%; Methanol 100\%). The dryed fractions obtained were subjected to antidiabetic, antioxidant and cytotoxicity assays.

\section{Antidiabetic assay}

Measurement of $\alpha$-glucosidase inhibition activity was performed according to the method of Kim, et al., (2004) with slightly modification. Solution of p-nitrophenyl- $\alpha$-D-glucopyranoside (Sigma) $5 \mathrm{mM}(25 \mu \mathrm{L})$ and $0.1 \mathrm{M}$ phosphate buffer pH $7(50 \mu \mathrm{L})$ was added to a microplate containing $5 \mu \mathrm{L}$ sample solution in DMSO (Merck, New Jersey, USA) to give final concentration $5 \mu \mathrm{g} / \mathrm{mL}$.
The solution was preincubated for $5 \mathrm{~min}$ at $37^{\circ} \mathrm{C}$, the reaction was initiated by addition of $25 \mu \mathrm{L}$ solution of 0.063 units $\alpha$-glucosidase (TCI, Tokyo, Japan), and incubated for the next 15 minutes. The reaction was stopped by addition of $95 \mu \mathrm{L}$ of $0.2 \mathrm{M} \mathrm{Na}_{2} \mathrm{CO}_{3}$ (Merck). The enzyme activity was measured by reading absorbance of p-nitrophenol formed at $\lambda 400 \mathrm{~nm}$ (Varioskan Flash, Thermo Fisher, Massachusetts, USA).

\section{Antioxidant assay}

The $\alpha, \alpha$-diphenyl- $\beta$-picrylhydrazyl (DPPH) free radical scavenging activity was conducted according to Yen and Chen (1995). Sample was dissolved in methanol (Merck), $5 \mu \mathrm{L}$ sample was pipette into the microplate (Nunc, Roskilde, Denmark). Then, $40 \mu \mathrm{L}$ methanol solution of $1 \mathrm{mM}$ DPPH (Sigma, Missouri, USA) was added to the sample solution, and followed with $155 \mu \mathrm{L}$ methanol was added to give final concentration of the sample was $5 \mu \mathrm{g} / \mathrm{mL}$. Absorbance was measured at $515 \mathrm{~nm}$ (Varioskan Flash, Thermo Fisher).

\section{Cell culture and in vitro cytotoxic activity examination}

Breast cancer cell line T47D was kindly provided by Prof. Dr. Edy Meiyanto (Faculty of Pharmacy, Universitas Gadjah Mada, Yogyakarta) and maintained in Research Center for Chemistry, Indonesian Institute of Sciences (Lembaga Ilmu Pendidikan Indonesia/LIPI). The cell lines were cultivated at $37^{\circ} \mathrm{C}$ with $5 \% \mathrm{CO}_{2}$ in RPMI1640 (GIBCO, Massachusetts, USA) medium supplemented with $10 \%$ v/v Fetal Bovine Serum (Sigma), 1\% antibiotic-antimycotic (GIBCO). Cell suspensions $\left(5 \times 10^{4}\right.$ cells $\left./ \mathrm{mL}\right)$ were seeding to each well and the cells were incubated for at $37^{\circ} \mathrm{C}$ under $5 \% \mathrm{CO}_{2}$. After 24 hours, samples were added and microscopic observation was conducted after 24 hour incubation, AlamarBlue reagent (Thermo Fisher) was added to the sample for quantitative fluorometric measurement of cytotoxicity activity (Varioskan Flash, Thermofisher). 


\section{RESULTS}

Seven fractions (F1-7) were obtained from column chromatography using various solvents (Table 1). F1 was not analyzed for bioactivities since the yield obtained only $2.9 \mathrm{mg}(0.06 \%)$, which suggest that $70 \%$ ethanol extract of $S$. cumini might only has small amount of non-polar compounds. The semi-polar to polar fractions (F5-7) was considered as the major content that gives yield $66.33 \%$ whereas the more semi-polar fractions (F2-4) were only $36.61 \%$. Table 1 showed the comparison of antidiabetic, antioxidant and cytotoxic activities of F2-7. The results showed that F2-F4 exhibited a good cytotoxic activity, F5-F7 exhibited a good antidiabetic activity and F4-F7 exhibited a good antioxidant activity. The best antidiabetic activity was found in F5 (93\% $\alpha$-glucosidase inhibitory activity), the best antioxidant activity was found in F4 (83\% inhibition of DPPH free radical) and the best cytotoxic activity was found in F2 (69\% growth inhibition of T47D breast cancer cell line) which also shown in Figure 1. T47D cells on F2F4 treatment showed morphological alteration compared to untreated cells. Most of dead cells was observed on F2-F4 treatment as black dot that not attached to the well that showed its good cytotoxic activity toward cancer cells. But then, treatment of F5-F7 did not alter the morphology of T47D cells compared to untreated cells.

\section{DISCUSSION}

Although the highest antidiabetic activity as $\alpha$-glucosidase inhibitor were found on F5, activities of F6 and F7 were also significantly high (88\% inhibitory activity to $\alpha$-glucosidase). Therefore further attempt to isolate the active antidiabetic compounds from these 3 fractions currently still in progress which will support our previous finding that the $70 \%$ ethanol leaves extract has in vitro and in vivo antidiabetic activities. This finding was in accordance with studies reported by Sanches, et al., (2016).

Besides its antidiabetic activity, fraction F5-7 also showed excellent antioxidant as DPPH free radical scavenged. This suggest F5-7 containing compounds that have both activities such as flavonoid and phenolic compounds. Whereas F4 containing compound that having the best antioxidant activity and average cytotoxic activity. One of mechanism of action of anticancer drug is

Table 1. Antidiabetic, antioxidant and cytotoxic activities of S.cumini fractions.

\begin{tabular}{|c|c|c|c|c|c|}
\hline Fraction & Eluent & $\begin{array}{c}\text { Dry Weight } \\
\text { (mg) }\end{array}$ & $\begin{array}{c}\text { Antidiabetic** } \\
(\alpha \text {-glucosidase } \\
\text { inhibitory activity) } \\
(\%)\end{array}$ & $\begin{array}{c}\text { Antioxidant** } \\
\text { (DPPH free radical } \\
\text { scavenging activity) } \\
(\%)\end{array}$ & $\begin{array}{c}\text { Cytotoxicity } * * * \\
\text { (against breast cancer } \\
\text { cell line T47D) } \\
(\%)\end{array}$ \\
\hline F1 & Hexane $100 \%$ & 2.9 & Not determined & Not determined & Not determined \\
\hline $\mathrm{F} 2$ & Hexane: Ethyl Acetate $50 \%$ & 978 & 36 & 9 & 68 \\
\hline F3 & Ethyl Acetate $100 \%$ & 627 & 41 & 31 & 56 \\
\hline F4 & Ethyl Acetate: Methanol 25\% & 245 & 44 & 83 & 50 \\
\hline F5 & Ethyl Acetate: Methanol 50\% & 2000 & 97 & 81 & 8 \\
\hline F6 & Ethyl Acetate: Methanol 75\% & 2000 & 88 & 82 & 7 \\
\hline F7 & Methanol 100\% & 1200 & 88 & 79 & 7 \\
\hline
\end{tabular}

Notes: Sample concentration $* *=5 \mu \mathrm{g} / \mathrm{mL} ; * * *=100 \mu \mathrm{g} / \mathrm{mL}$ 


\section{Untreated}

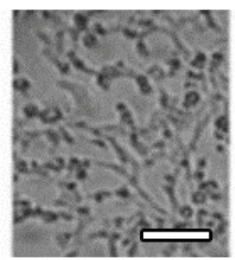

F2

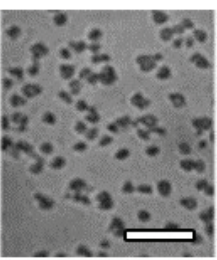

F3

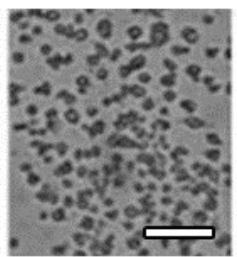

F4

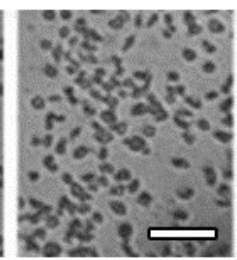

F5

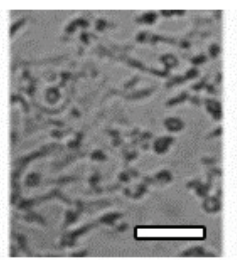

F6

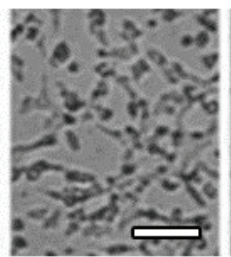

F7

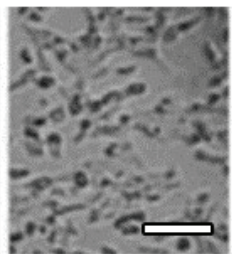

Figure 1. Morphological alteration of S. cumini fractions on T47D cells. Cells were treated with and without 100 $\mu \mathrm{g} / \mathrm{mL}$ of S.cumini fractions for $24 \mathrm{~h}$ and followed with alamarBlue cytotoxic assay. Scale bar=100 $\mu \mathrm{m}$.

related with mechanism of action of antioxidant (Lewandowski and Gwozdzinski, 2017). Then, it is reasonable that $\mathrm{F} 4$ exhibit antioxidant and also cytotoxic activity, but not all of fractions of $\mathrm{S}$. cumini that show antioxidant activity also perform cytotoxic activity. Antioxidant activity as DPPH free radical scavenging activity of $S$. cumini leaves also reported by Ruan, et al., (2008) in methanol extract and its fractions (water, ethyl acetate $(\mathrm{EaF})$, chloroform $(\mathrm{CfF})$, and $\mathrm{n}$-hexane $(\mathrm{HxF})$ fractions); by Mohamed, et al., (2013) in methanol extract, dichlormethane extract and essential oils; by Ecker, et al., (2015) in aqueous extract.

As shown in fluorometric measurement and microscopic observation, the good cytotoxic activity against T47D breast cancer cell line were only shown in fraction F2-4 (more than 50\%), whereas fraction F5-7 only showed very low activity (less than 10\%). Anticancer activity of $S$. cumini was also reported by Aqil, et al., (2016); Barh and Viswanathan, (2008); Goyal, et al., (2010); and Parmar, et al., (2010). Interestingly, this study revealed that most of $S$. cumini active fraction for antidiabetic and antioxidant had differ polarity compared with its active fraction for anticancer. $S$. cumini leaves contains non polar compounds, such as $\beta$-sitosterol, essential oil (pinocarveol, myrtenol), triterpene (betulinic acid), semi polar compounds such as flavonoid (quercetin, myricetin) and polar compounds such as glycoside derivatives of flavonoid (Subramanian, et al., 2013). Essential oil, $\beta$-sitosterol, betulinic acid and semi-polar flavonoid from other plant show cytotoxic activity on various cancer cells (Baskar, et al., 2010; Raja, et al., 2017; Urban, et al., 2012; Zorzetto, et al., 2015). Flavonoid quercetin and its glycoside had been studied for its antioxidant and antidiabetic activities (Eid, et al., 2010; Panat, et al., 2015; Zheng, et al., 2017). This study come to a suggestion that the potential anticancer compounds of $S$. cumini leaves might be differed from its potential antidiabetic and antioxidant compounds. Non polar and semipolar flavonoid of S. cumini may have a role on its cytotoxic activity. On the other hand, the more polar compounds of $S$. cumini may have a role on its antidiabetic and antioxidant activity. Nevertheless, the advance study need to be done to explore the active compounds that have a role on each activity.

\section{CONCLUSION}

The results showed that besides the antidiabetic activity, the fractions from S. cumini leaves EtOH extract also showed antioxidant and cytotoxic activities. Since the most active fractions for antidiabetic, antioxidant and cytotoxicity were differed, it could be possible to isolate the different potential active compounds for each activity.

\section{ACKNOWLEDGEMENT}

We thank to Mr. Ngadiman from Research Center for Chemistry, Indonesian Institute of Sciences (LIPI) for conducting the extraction. 
This work was supported by research funding for 'Penelitian Unggulan untuk Ketahanan Pangan dan Obat LIPI 2016 '.

\section{REFERENCES}

Aqil, F., Jeyabalan, J., Munagala, R., Singh, I.P. and Gupta, R.C., 2016, Prevention of Hormonal Breast Cancer by Dietary Jamun, Mol. Nutr. Food Res., 60(6), 1470-1481.

Ayyanar, M. and Subash-Babu, P., 2012, Syzygium cumini (L.) Skeels: A Review of Its Phytochemical Constituents and Traditional Uses, Asian Pac. J. Trop. Biomed., 2(3), 240-246.

Barh, D. and Viswanathan, G., 2008, Syzygium cumini Inhibits Growth and Induces Apoptosis in Cervical Cancer Cell Lines: A Primary Study. Ecancermedicalscience, 2, 83. doi: 10.3332/ ecancer.2008.83.

Baskar, A.A., Ignacimuthu, S., Paulraj, G.M. and Al Numair, K.S., 2010. Chemopreventive Potential of B-Sitosterol in Experimental Colon Cancer Model - An In vitro and In vivo Study. BMC Complement. Altern. Med., 10, 24. doi: 10.1186/1472-6882-10-24.

Ecker, A., Araujo Vieira, F., de Souza Prestes, A., Mulling dos Santos, M., Ramos, A., Dias Ferreira, R., et al., 2015. Effect of Syzygium cumini and Bauhinia forficata Aqueous-leaf Extracts on Oxidative and Mitochondrial Parameters in vitro, EXCLI J, 14, 1219-1231.

Eid, H.M., Martineau, L.C., Saleem, A., Muhammad, A., Vallerand, D., Benhaddou-Andaloussi, A., et al., 2010. Stimulation of AMP-activated Protein Kinase and Enhancement of Basal Glucose Uptake in Muscle Cells by Quercetin and Quercetin Glycosides, Active Principles of the Antidiabetic Medicinal Plant Vaccinium vitis-idaea, Mol. Nutr. Food Res., 54(7), 9911003.

Goyal, P.K., Verma, P., Sharma, P., Parmar, J. and Agarwal, A., 2010, Evaluation of Anti-cancer and Anti-oxidative Potential of Syzygium Cumini against Benzo[a]pyrene (BaP) Induced Gastric Carcinogenesis in Mice, Asian Pac. J. Cancer Prev., 11(3), 753-758.
Kim, Y.M., Wang, M.H. and Rhee, H.I., 2004, A Novel Alpha-glucosidase Inhibitor from Pine Bark, Carbohydr. Res., 339(3), 715-717.

Lewandowski, M. and Gwozdzinski, K., 2017, Nitroxides as Antioxidants and Anticancer Drugs, Int. J. Mol. Sci., 18(11), pii: E249. doi: 10.3390/ijms 18112490 .

Mohamed, A.A., Ali, S.I. and El-Baz, F.K., 2013, Antioxidant and Antibacterial Activities of Crude Extracts and Essential Oils of Syzygium cumini Leaves, PloS One, 8(4), e60269. doi: 10.1371/ journal.pone.0060269.

Panat, N., Amrute, B., Bhattu, S., Haram, S., Sharma, G. and Ghaskadbi, S., 2015, Antioxidant Profiling of C3 Quercetin Glycosides: Quercitrin, Quercetin 3-B-D-glucoside and Quercetin 3-0-(6"-O-malonyl)-B-Dglucoside in cell free environment, Free Radic. Anioxdants., 5(2), 90-100.

Parmar, J., Sharma, P., Verma, P. and Goyal, P.K., 2010, Chemopreventive Action of Syzygium cumini on DMBA-induced Skin Papillomagenesis in Mice, Asian Pac. J. Cancer Prev., 11(1), 261265.

Raja, S.B., Rajendiran, V., Kasinathan, N.K., P, A., Venkatabalasubramanian, S., Murali, M.R., et al., 2017, Differential Cytotoxic Activity of Quercetin on Colonic Cancer Cells Depends on ROS Generation through COX-2 Expression, Food Chem. Toxicol., 106(Pt A), 92-106.

Ruan, Z.P., Zhang, L.L. and Lin, Y.M., 2008, Evaluation of the Antioxidant Activity of Syzygium cumini Leaves, Mol. Basel Switz, 13(10), 2545-2556.

Sanches, J.R., França, L.M., Chagas, V.T., Gaspar, R.S., Dos Santos, K.A., Gonçalves, L.M., et al., 2016. Polyphenol-Rich Extract of Syzygium cumini Leaf Dually Improves Peripheral Insulin Sensitivity and Pancreatic Islet Function in Monosodium L-Glutamate-Induced Obese Rats, Front. Pharmacol., 7, 48. doi: 10.3389/ fphar.2016.00048.

Subramanian, R., Neethirajan, K. and Ramaraj, J., 2013, Profile of Bioactive Compounds in Syzygium cumini - A Review, J. Pharm. Res., 20125, 4548-4553. 
Tripathy, G. and Pradhan, D., 2015. In-Vitro Anti Breast Cancer Activity of Syzygium Cumini Against MCF-7 Cell Line, J. Innov. Pharm. Biol. Sci., 2(2), 119-124.

Urban, M., Vlk, M., Dzubak, P., Hajduch, M. and Sarek, J., 2012, Cytotoxic Heterocyclic Triterpenoids Derived from Betulin and Betulinic Acid, Bioorg. Med. Chem., 20(11), 3666-3674.

Zheng, Y.Z., Deng, G., Liang, Q., Chen, D.F., Guo, R. and Lai, R.C., 2017, Antioxidant Activity of
Quercetin and Its Glucosides from Propolis: A Theoretical Study, Sci. Rep., 7, 7543. doi: 10.1038/s41598-017-08024-8

Zorzetto, C., Sánchez-Mateo, C.C., Rabanal, R.M., Lupidi, G., Bramucci, M., Quassinti, L., et al., 2015, Antioxidant Activity and Cytotoxicity on Tumour Cells of The Essential Oil from Cedronella canariensis var. canariensis (L.) Webb \& Berthel. (Lamiaceae), Nat. Prod. Res., 29(17), 1641-1649. 